\title{
2-Thiophene Carboxaldehyde as Corrosion Inhibitor for Zinc in Phosphoric Acid Solution
}

\author{
M. BOULKROUNE* and A. CHIBANI
}

Laboratoire de Chimie Moléculaire, du Contrôle de l'Environnement, et de Mesures physico-chimiques, Université Mentouri, route de Ain El-Bey, Constantine, Algérie minaboulkroune@yahoo.fr

Received 15 May 2012 / Accepted 20 June 2012

\begin{abstract}
The inhibitive effect of 2-thiophene carboxaldehyde (TCAl) on zinc corrosion in $1 \mathrm{M} \mathrm{H}_{3} \mathrm{PO}_{4}$ solutions has been studied by weight loss, potentiodynamic polarisation and open-circuit potential (OCP) methods. The obtained results revealed that TCAl is an effective corrosion inhibitor for zinc in $\mathrm{H}_{3} \mathrm{PO}_{4}$ solutions. Inhibition efficiency values obtained from gravimetric and electrochemical measurements were in good agreement. The inhibition efficiency increases with increasing inhibitor concentration and decreases with increasing temperature. Potentiodynamic polarisation studies showed that TCAl acts as a mixed type inhibitor. Scanning electron microscopy (SEM), OCP measurements and the thermodynamic data of dissolution and adsorption processes showed that inhibition of zinc corrosion in phosphoric acid solutions by TCAl is due to the formation of a physisorbed film on the zinc surface. Adsorption of the compound studied on zinc surface obeys to Langmuir adsorption isotherm.
\end{abstract}

Keywords: Corrosion, Inhibition, Zinc, Acid, Thiophene, Adsorption

\section{Introduction}

Corrosion control of metals is an activity of technical, economical, environmental and aesthetical importance. Thus, the search for new and efficient corrosion inhibitors has become a necessity to secure metallic materials against corrosion.

Acid solutions are generally used for the removal of undesirable scale and rust in several industrial process. Since acids are aggressive, inhibitors are usually used to control the metal dissolution. The use of organic compounds as corrosion inhibitors in acidic media have been widely reported by several authors ${ }^{1-10}$.

Zinc finds numerous applications in technology and industry. Consequently, the study of its corrosion inhibition is of great importance. A survey of literature reveals that there are very few substances, which may be considered as good inhibitors for corrosion of zinc in acidic media. These include the inhibitive action of phosphonium salts ${ }^{11,12}$, organic dyes ${ }^{13}$, substituted $N$-arylpyrroles ${ }^{14}$, organic onium compounds ${ }^{15}$, ethoxylated fatty alcohols ${ }^{16}$, 2-mercaptobenzimidazole ${ }^{17}$ Schiff bases of ethylenediamine ${ }^{18}$, ethoxylated fatty acids ${ }^{19}$, and $m$-substituted aniline- $N$-salicylidenes ${ }^{20}$. 
Some thiophene compounds have been reported earlier as good inhibitors for steel and AISI austenitic stainless steel in acidic media ${ }^{21-25}$. In the present work, the corrosion inhibition of 2-thiophene carboxaldehyde for zinc in $1 \mathrm{M} \mathrm{H}_{3} \mathrm{PO}_{4}$ solution has been studied by weight loss and electrochemical methods. The efficiency of the inhibitors was evaluated at various concentrations and temperatures. Surface examinations were made using scanning electron microscopy (SEM). The molecular structure of the thiophene studied is shown in Figure 1.<smiles>O=Cc1cccs1</smiles>

(TCAl)

Figure 1. Molecular structure of 2-thiophene carboxaldehyde

\section{Experimental}

All solutions were prepared using distilled water and commercial products. Thiophene carboxaldhyde 98\% (TCAl) was Fluka product and was used as received. The aggressive solution $\left(1 \mathrm{M} \mathrm{H}_{3} \mathrm{PO}_{4}\right)$ was prepared by dilution of analytical grade $85 \% \mathrm{H}_{3} \mathrm{PO}_{4}$ (Merck). Zinc specimens were cut from industrial zinc ( $0.9 \mathrm{~mm}$ thickness).

\section{Weight loss measurements}

Gravimetric measurements were carried out in a double walled glass cell equipped with a thermostated cooling condenser. Weight loss was measured on sheets of zinc of apparent surface area of $2 \mathrm{~cm}^{2}$. Prior to all measurements, the zinc samples were mechanically abraded using a series of emery paper from 400 to 1200 grade. The specimens were then rinsed with distilled water, degreased with acetone, rinsed again with distilled water and finally dried before being weighed and immersed in $100 \mathrm{~cm}^{3}$ of the corrosive solution at $298 \pm 0.5 \mathrm{~K}$. At the end of the tests, the specimens were taken out from the solution at regular intervals of time (10-90 min), rinsed with distilled water, degreased with acetone, dried and weighed using an analytical balance.

\section{Electrochemical measurements}

Electrochemical measurements were carried out in a conventional three-electrode cylindrical glass cell with a thermostatic jacket and a disc sample holder. The working electrode had the form of a disc cut form zinc sheet. The exposed area to the corrosive solution was $0.95 \mathrm{~cm}^{2}$. The electrode surface was prepared in a similar way as used in case of weight loss measurements. A saturated calomel electrode (SCE) and a platinum electrode were used as reference and auxiliary electrode, respectively. The temperature was thermostatically controlled at $298 \pm 0.5 \mathrm{~K}$. Electrochemical measurements were done using PGP 201 potentiostat/galvanostat controlled by Volta Master 1 corrosion software.

\section{Polarisation measurements}

The polarisation curves were recorded after the electrode potential reaches a steady-state value. The polarisation curves are obtained from $-1090 \mathrm{mV} / \mathrm{SCE}$ to more positive values at a scan rate of $20 \mathrm{mV} / \mathrm{min}$. The test solution is deaerated with pure nitrogen. Gas bubbling is maintained through the experiments. Corrosion current density values were obtained by Tafel extrapolation method. 


\section{Open circuit measurements}

The variation of the open circuit potential (OCP) of the zinc electrode was followed as a function of time from the moment of its introduction into the cell during 1 hour.

\section{SEM}

Scanning electron microscopy (SEM) observations of $\mathrm{Zn}$ surface before and after immersion in acid solution in the absence and the presence of the inhibitor were performed using scanning electron microscopy (SEM) Jeol JSM-6400 model.

\section{Results and Discussion}

\section{Weight loss measurements}

\section{Effect of TCAl concentration}

Since corrosion inhibitors may accelerate corrosion when used at low concentrations or may cause emulsification when used at high concentrations ${ }^{16}$, it was necessary to study the effect of 2-thiophene carboxaldehyde concentration on zinc corrosion.

The corrosion rates in $1 \mathrm{M} \mathrm{H}_{3} \mathrm{PO}_{4}\left(W_{\text {corr }}^{0}\right)$ and at different concentrations of the tested compound $\left(W_{\text {corr }}\right)$ are determined after $1 \mathrm{~h}$ of immersion. The values of corrosion rates and inhibition efficiencies are given in Table 1 . The inhibition efficiency $\left(I E_{w}\right)$ was calculated using the equation:

$$
I E_{w}=100 \times\left(1-\frac{W_{c o r r}}{W_{c o r r}^{0}}\right)
$$

It is clear from Table 1 that the corrosion rate decreases in the presence of TCAl and that it depends on the inhibitor concentration, hence, the inhibition efficiency increases with the inhibitor concentration to reach near $97 \%$ at $5 \times 10^{-3} \mathrm{M}$. This trend may result from the fact that adsorption and surface coverage increases with the increase in TCAl concentration; thus the surface is separated from the medium ${ }^{26}$.

Table 1. Gravimetric results of zinc corrosion in $1 \mathrm{M} \mathrm{H}_{3} \mathrm{PO}_{4}$ without and with various concentrations of TCAl at $298 \mathrm{~K}$ after $1 \mathrm{~h}$ of immersion period

\begin{tabular}{ccc}
\hline Concentration, $\mathrm{M}$ & $W_{\text {corr }} \mathrm{mg} / \mathrm{cm}^{2} \mathrm{~h}$ & $I E_{w}, \%$ \\
\hline Blank TCAl & 33.4 & - \\
$5 \times 10^{-4}$ & 15.8 & 52.69 \\
$1 \times 10^{-3}$ & 11.28 & 66.28 \\
$2 \times 10^{-3}$ & 4.95 & 85.18 \\
$3 \times 10^{-3}$ & 3.65 & 89.07 \\
$4 \times 10^{-3}$ & 2.00 & 94.01 \\
$5 \times 10^{-3}$ & 1.15 & 96.56 \\
$6 \times 10^{-3}$ & 1.35 & 95.95 \\
$7 \times 10^{-3}$ & 1.25 & 96.26 \\
\hline
\end{tabular}

\section{Effect of immersion time}

To elucidate the influence of immersion time on the corrosion rate of zinc, the data obtained from weight loss measurements for different periods are collected in Figure 2. The curves show the variation of the weight loss of zinc with the immersion time in $1 \mathrm{M} \mathrm{H}_{3} \mathrm{PO}_{4}$ solutions without and with TCAl at the concentrations $10^{-3} \mathrm{M}$ and $5 \times 10^{-3} \mathrm{M}$. 
From these data, it is obvious that the weight loss of zinc enhances with immersion time. On the other hand, addition of increasing concentrations of the inhibitor, retards the corrosion of zinc in these solutions. This is clearly seen from the decrease in weight loss, corresponding to a noticeable decrease in the slope of each curve, with increase in inhibitor concentration. These results indicate that the compound under investigation does not lose its efficiency after long periods of immersion.

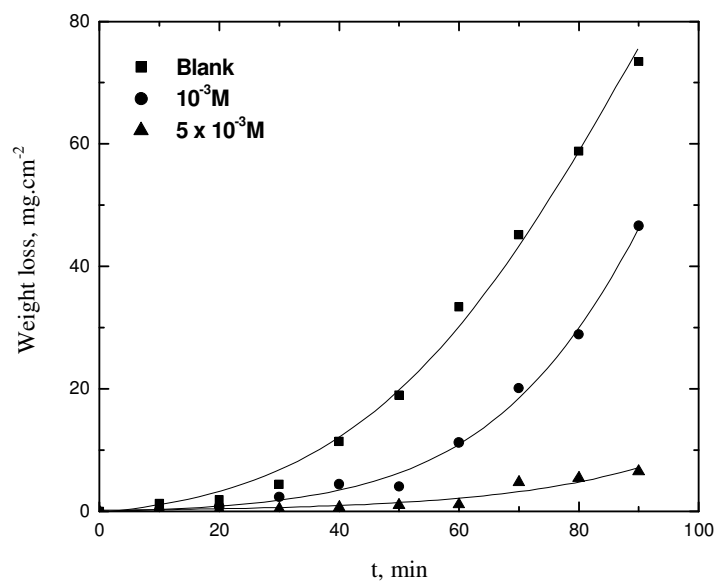

Figure 2. Weight loss of zinc as function of immersion time in $1 \mathrm{M} \mathrm{H}_{3} \mathrm{PO}_{4}$ solution without and with TCAl at $298 \mathrm{~K}$

\section{Polarisation measurements}

The potentiodynamic polarisation curves of zinc in phosphoric acid in the absence and presence of the tested inhibitor are shown in Figure 3. Electrochemical parameters obtained from the Tafel extrapolation method are given in Table 2 . The inhibition efficiencies were calculated using the following equation:

$$
I E_{I}=100 \times\left(1-\frac{I_{\text {corr }}}{I_{\text {corr }}^{0}}\right)
$$

Where $I_{\text {corr }}$ and $I_{\text {corr }}^{0}$ are the corrosion current density values with and without the inhibitor, respectively.

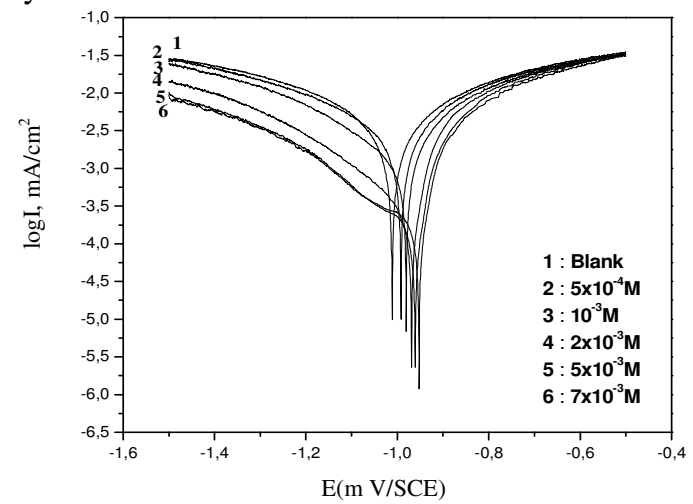

Figure 3. Potentiodynamic polarization curves for zinc in $1 \mathrm{M} \mathrm{H}_{3} \mathrm{PO}_{4}$ containing different concentrations of TCAl 
Table 2. Electrochemical parameters and the corresponding corrosion inhibition efficiencies of zinc in $1 \mathrm{M} \mathrm{H}_{3} \mathrm{PO}_{4}$ without and with various concentration of TCAl at $298 \mathrm{~K}$

\begin{tabular}{cccccc}
\hline Concentration, $\mathrm{M}$ & $E_{\text {corr }}, \mathrm{mV} / \mathrm{SCE}$ & $I_{\text {corr }}, \mathrm{mA} / \mathrm{cm}^{2}$ & $b_{a}, \mathrm{mV} / \mathrm{dec}$ & $b_{c}, \mathrm{mV} / \mathrm{dec}$ & $I E_{l}, \%$ \\
\hline Blank TCA1 & -1011 & 6.637 & 789.4 & -701.8 & - \\
$5 \times 10^{-4}$ & -993 & 4.8305 & 676.3 & -614.8 & 27.22 \\
$10^{-3}$ & -981 & 2.897 & 633.4 & -502.7 & 56.35 \\
$2 \times 10^{-3}$ & -969 & 0.8453 & 600 & -389.7 & 87.26 \\
$5 \times 10^{-3}$ & -961 & 0.1795 & 511.9 & -306.7 & 97.29 \\
$7 \times 10^{-3}$ & -954 & 0.2084 & 495.3 & -434.4 & 96.86 \\
\hline
\end{tabular}

The corrosion of zinc in acidic solution is the result of the galvanic cell of the anodic dissolution of zinc and the cathodic evolution of hydrogen ${ }^{27}$. From electrochemical polarisation measurements, it is clearly seen that TCAl shifts both the anodic and cathodic branches of the polarization curves of the pure acid solution to lower values of current density, but inhibits the hydrogen evolution reaction more than the anodic dissolution of zinc.

$I E_{I}(\%)$ values increase with increasing inhibitor concentration reaching a maximum value at $5 \times 10^{-3} \mathrm{M}$ (Table 2). These results are in good agreement with those obtained from the gravimetric tests.

Increase in concentration of TCAl causes shifting of corrosion potentials to noble direction. According to Ferreira et al. ${ }^{28}$ and $\mathrm{Li}$ et $a{ }^{29}{ }^{29}$, if the displacement in corrosion potential is more than $85 \mathrm{mV}$ with respect to corrosion potential of the blank, the inhibitor can be considered as a cathodic or an anodic type. However, the maximum displacement in this study is $57 \mathrm{mV}$, which indicates that TCAl is a mixed type inhibitor. The changes in both the anodic and cathodic Tafel slopes observed on the addition of TCAl indicate that both anodic and cathodic reactions are affected by the addition of the inhibitor.

\section{Open-circuit potential measurements}

The open-circuit potentials of zinc in the absence and the presence of TCAl at different concentrations were traced over $60 \mathrm{~min}$ from the electrode immersion in the test solution. The obtained results are depicted in Figure 4.

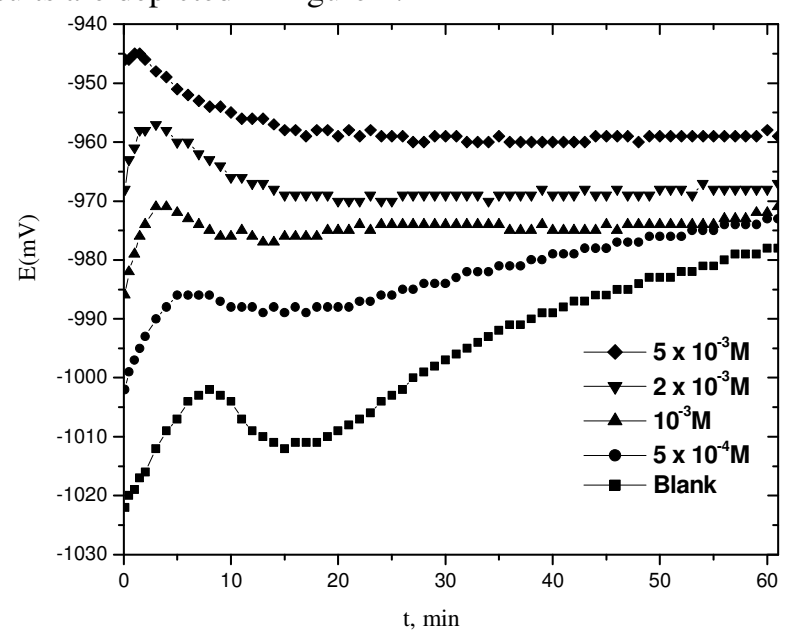

Figure 4. Open circuit potential variation of zinc in $1 \mathrm{M} \mathrm{H}_{3} \mathrm{PO}_{4}$ without and with various concentrations TCAl 
The dependence of OCP on time at various concentrations of TCAl is clearly seen from Figure 6. The presence of TCAl in the acidic solution shifts the steady-state potential towards noble values. This potential gets more positive as the additive concentration increases. The potential shift reveals that the inhibition efficiency of TCAl is enhanced. This behavior can be interpreted by the formation of a protective film on the electrode surface ${ }^{26,30}$.

\section{Temperature effect}

The effect of temperature on the inhibitive efficiency of TCAl was studied by gravimetric method at various temperatures. Weight losses were determined in $1 \mathrm{M}$ phosphoric acid solutions without and with $10^{-3} \mathrm{M}$ of the inhibitor studied in the temperature range (298-338 K), after $1 \mathrm{~h}$ of immersion.

The results given in Table 3 show that in inhibited as well as in uninhibited solutions the corrosion rate increases with a rise in temperature and as a result the inhibition efficiency decreases indicating that at higher temperatures the dissolution of Zinc predominates over inhibitor adsorption. This may be attributed to the desorption of the inhibitor molecules, thus exposing the metal surface to further attack ${ }^{18}$.

Table 3. Corrosion parameters and inhibition efficiencies for zinc in $1 \mathrm{M} \mathrm{H}_{3} \mathrm{PO}_{4}$ without and with the addition of TCAl $10^{-3} \mathrm{M}$ at different temperatures

\begin{tabular}{cccc}
\hline$T, \mathrm{~K}$ & $W_{\text {corr }}^{\circ} \mathrm{mg} / \mathrm{cm}^{2} \mathrm{~h}$ & $W_{\text {corr }} \mathrm{mg} / \mathrm{cm}^{2} \mathrm{~h}$ & $E w, \%$ \\
\hline 298 & 33.4 & 11.28 & 66.23 \\
308 & 67.05 & 24.3 & 63.76 \\
318 & 98.65 & 44.63 & 54.76 \\
328 & 154.6 & 78.15 & 49.45 \\
338 & 207.6 & 135.8 & 34.59 \\
\hline
\end{tabular}

The activation energy (Ea) of the corrosion process can be determined from the Arrhenius plots (ln $W_{\text {corr. }}$ Vs. $1 / T$ ) presented in Figure 5 by using the following equation ${ }^{31}$ :

and logarithmic form:

$$
W_{\text {corr. }}=A e^{-E a / R T}
$$

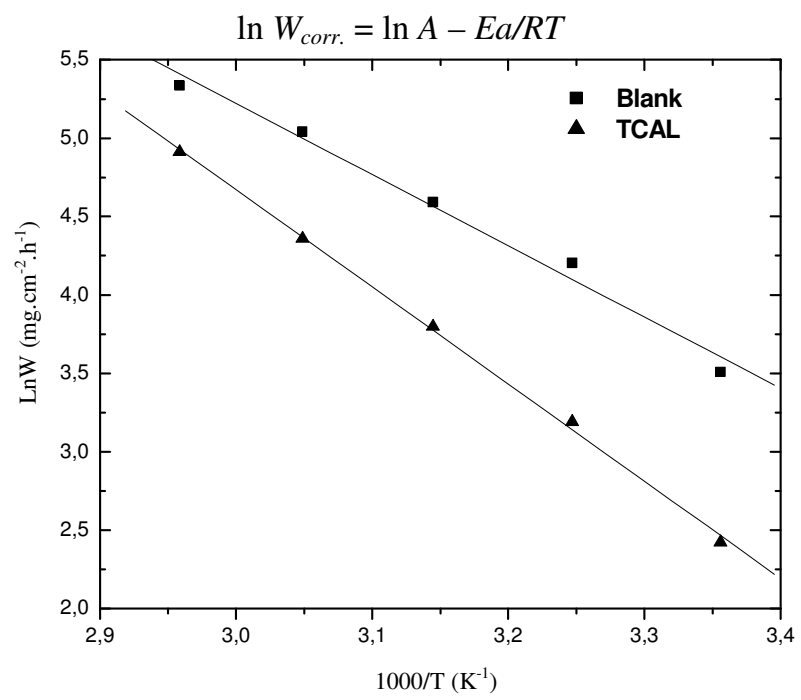

Figure 5. Arrhenius plots of zinc in $1 \mathrm{M} \mathrm{H}_{3} \mathrm{PO}_{4}$ without and with TCAl $10^{-3} \mathrm{M}$ 
Where $W_{\text {corr }}$ is the corrosion rate, $A$ is Arrhenius constant, $R$ is the universal gas constant and $\mathrm{T}$ is the absolute temperature. The values of the activation energies in the absence and presence of TCAl, respectively, were obtained from the slope of the straight lines and collected in Table 4. An alternative formulation of the Arrhenius equation is the transition state equation ${ }^{19,32,33}$ :

$$
W_{\text {corr. }}=R T / N h \exp (\Delta S / R) \exp (-\Delta H / R T)
$$

Where $h$ is Planck's constant, $N$ is Avogadro's number, $\Delta H$ and $\Delta S$ are the enthalpy and the entropy of activation, respectively. Figure 6 shows plots of $\ln \left(W_{\text {corr }} / T\right)$ against $(1 / T)$. Straight lines are obtained with a slope of $(-\Delta H / R)$ and an intercept of $(\ln R / N h+\Delta S / R)$ from which the values of $\Delta H$ and $\Delta S$ are calculated and listed in Table 4.

Table 4. Activation parameters of the zinc dissolution process in $1 \mathrm{M} \mathrm{H}_{3} \mathrm{PO}_{4}$ in the absence and the presence of TCAl $10^{-3} \mathrm{M}$

\begin{tabular}{rccc}
\hline & $E a, \mathrm{~kJ} / \mathrm{mol}$ & $\Delta H, \mathrm{~kJ} / \mathrm{mol}$ & $\Delta S, \mathrm{~J} / \mathrm{mol} . \mathrm{K}$ \\
\hline $\mathrm{H}_{3} \mathrm{PO}_{4} 1 \mathrm{M}$ & 37.76 & 35.13 & -97.05 \\
$\mathrm{TCAl} 10^{-3} \mathrm{M}$ & 51.55 & 48.91 & -60.26 \\
\hline & & & \\
\hline
\end{tabular}

Figure 6. Plots of $\log (W / T)$ vs. $1 / T$ for zinc in $1 \mathrm{M} \mathrm{H}_{3} \mathrm{PO} 4$ without and with $\mathrm{TCAl} 10^{-3} \mathrm{M}$

The addition of TCAl leads to an increase in the activation energy. Generally, a decrease in inhibition efficiency with rise in temperature and the higher value of Ea in the presence of the inhibitor is often regarded as indicative of physical adsorption ${ }^{3,7}$.

We note also that the positive values of $\Delta H$ reflect the endothermic nature of zinc dissolution process. In addition, the value of $\Delta S$ is negative and becomes higher in the presence of TCAl. This implies that the decrease in a disordering takes place on going from reactants to activated complex ${ }^{34,35,8}$.

\section{Adsorption isotherm}

Many adsorption isotherms were plotted and the Langmuir adsorption isotherm was found to provide best description of the adsorption behaviour of the studied inhibitor according to the following equation ${ }^{15}$ :

$$
\frac{C}{\theta}=\frac{1}{k}+C
$$


Where $C$ is the inhibitor concentration, $\theta$ the fraction of the surface covered determined by $\mathrm{E} / 100$ and $\mathrm{k}$ the equilibrium constant which is related to the standard free energy of adsorption $\Delta G_{a d s}^{0}$ by the equation ${ }^{15,36}$ :

$$
k=\frac{1}{55.5} \exp \left(-\frac{\Delta G_{a d s}^{0}}{R T}\right)
$$

The value of 55.5 is the concentration of water in solution expressed in M. Plotting $C / \theta$ against $C$ gave a straight line with a slope close to unity (Figure 7 ) indicating that the adsorption of TCAl on zinc surface follows Langmuir adsorption isotherm and consequently, there is no interaction between the adsorbed molecules ${ }^{33,37}$. The negative value obtained of $\Delta G_{a d s}^{0}\left(-28.94 \mathrm{~kJ} \mathrm{~mol}^{-1}\right)$ suggests that TCAl is spontaneously physisorbed on the metal surface ${ }^{5,38}$.

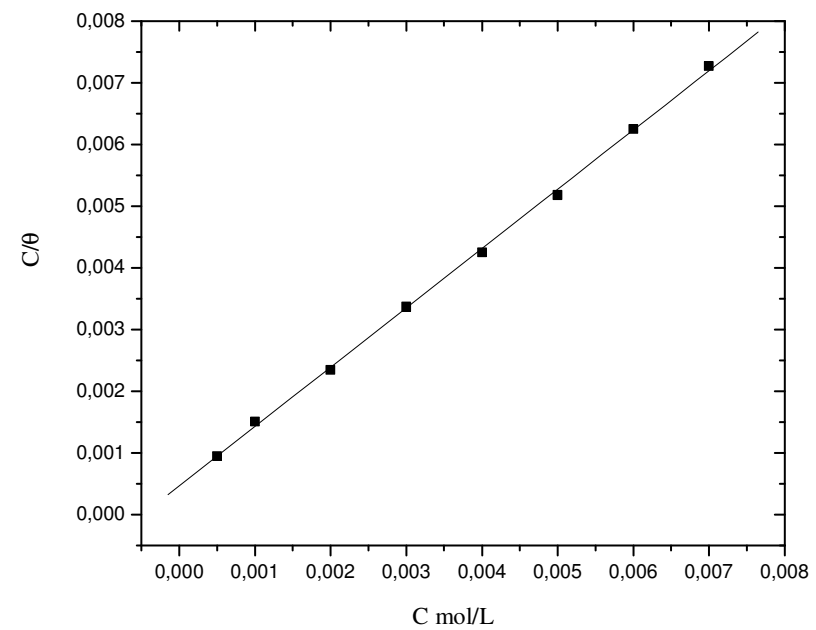

Figure 7. Langmuir adsorption isotherm of TCAl on the surface of zinc in $1 \mathrm{M} \mathrm{H}_{3} \mathrm{PO}_{4}$

\section{SEM measurement}

Scanning electron microscopy (SEM) was performed on the zinc surface before (Figure 8 (a)) and after immersion in corrosive solution in the absence (Figure 8 (b)) and presence of TCAl (Figure 8 (b)). It can be seen from Figure 8 (b) compared to Figure 8 (a) that the zinc surface is strongly damaged in the absence of the inhibitor. Figure 8 (c) shows that the surface of zinc in the presence of TCAl is nearly intact as even the original polishing scratches are seen after the exposure, indicating that TCAl can inhibit the corrosion of zinc significantly.

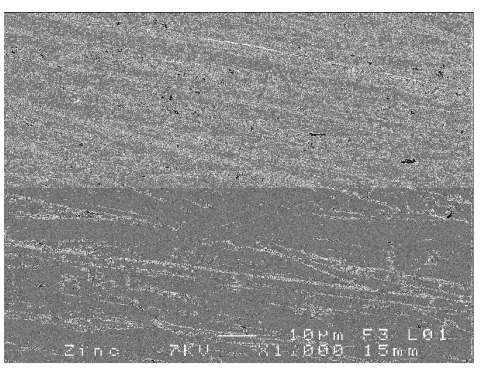

a

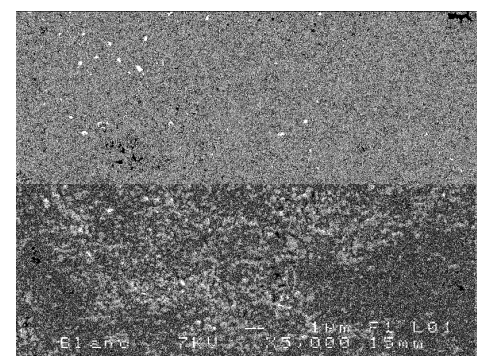

b 


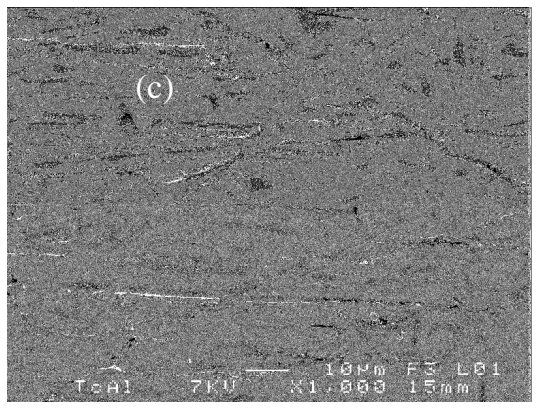

Figure 8. SEM images of zinc surface, before its exposure to electrolyte (a), after $1 \mathrm{~h}$ of immersion in $1 \mathrm{M} \mathrm{H}_{3} \mathrm{PO}_{4}$ in the absence (b) and presence (c) of TCAl $5 \times 10^{-3} \mathrm{M}$

\section{Conclusion}

From the above results, the following conclusions are made:

- 2-Thiophene carboxaldehyde is considered as a good inhibitor for zinc corrosion in $1 \mathrm{M} \mathrm{H}_{3} \mathrm{PO}_{4}$.

- The protection efficiency increases with increase in inhibitor concentration to reach to reach near $97 \%$ at $5 \times 10^{-3} \mathrm{M}$ and decreases with increase in temperature.

- The inhibition efficiencies obtained from polarization measurements shows good agreement with those obtained from weight loss method.

- $\quad$ Polarisation measurements show that TCAl acts as a mixed type inhibitor.

- The Scanning electron microscopy (SEM), OCP measurements and the thermodynamic parameters of dissolution and adsorption processes, indicate that the inhibition characteristic of TCAl is attributed to its physisorption on the zinc surface.

- The adsorption of TCAl on the Zinc surface obeys to the Langmuir adsorption isotherm model.

\section{References}

1. Wang L, Corros Sci., 2001, 43, 1637-1644.

2. Benchekroun K, Dalard F, Rameaub J J and El Ghazalic A, New J Chem., 2002, 26, 153-159.

3. Popova A, Sokolova E, Raicheva S and Christov M, Corros Sci., 2003, 45, 33-58.

4. Yurt A, Balaban A, Ustün Kandemir S, Bereket G and Erk B, Mater Chem Phys., 2004, 85(2), 420.

5. Ouchrif A, Zegmout M, Hammouti B, El-Kadiri S and Ramdani A, Appl Surf Sci., 2005, 252(2), 339-344.

6. Fouda A S, Mostafa H A and Moussa M N, Port Electrochim Acta, 2005, 23(2), 275-287.

7. Tebbji K, Aouniti A, Benkaddour M, Oudda H, Bouabdallah I, Hammouti B and Ramdani A, Prog Org Coat., 2005, 54, 170-174.

8. Benabdellah M, Ousslim A, Hammouti B, Elidrissi A, Aouniti A, Dafali A, Bekkouch K and Benkaddour M, J Appl Electrochem., 2007, 37(7), 819-826.

9. Quraishi M A, Rafiquee M Z A, Khan S and Saxena N, J Appl Electrochem., 2007, 37, 1153-1162.

10. Antonijevic M M and Petrovic M B, Int J Electrochem Sci., 2008, 3, 1-26.

11. Troquet M, Labbe J P and Pagetti J, Corros Sci., 1981, 21(2), 101-117. 
12. Troquet M and Pagetti J, Electrochem Acta, 1982, 27(2), 197-203.

13. Mourad M Y, Seliman S A and Abde El-Metaal S M, Bull Soc Chim Fr., 1991, 128, 832.

14. Stupnisek-Lisac E and Podbrscek S, J Appl Electrochem., 1994, 24, 779.

15. Morad M S, J Appl Electrochem., 1999, 29, 619-626.

16. Abdellah M, Corros Sci., 2003, 45, 2705.

17. Wang L, Pu J X and Luo H C, Corros Sci., 2003, 45(4), 677-683.

18. Agrawal Y K, Talati J D, Shah M D, Desai M N and Shah N K, Corros Sci., 2004, 46(3), 633-651.

19. Foad El-Sherbini E E, Abdel Wahaab S M and Deyab M, Mater Chem Phys., 2005, 89, 183-191.

20. Talati J D, Desai M N and Shah N K, Mater Chem Phys., 2005, 93(1), 54-64.

21. Bouklah M, Hammouti B, Aouniti A and Benhadda T, Prog Org Coat., 2004, 49(3), 225-228.

22. Galal A, Atta N F and Al-Hassan M H S, Mater Chem Phys., 2005, 89(1), 28-37.

23. Galal A, Atta N F and Al-Hassan M H S, Mater Chem Phys., 2005, 89, 38.

24. Benabdellah M, Aouniti A, Dafali A, Hammouti B, Benkaddour M, Yahyi A and Ettouhami A, Appl Surf Sci., 2006, 252, 8341.

25. Bouklah M, Hammouti B, Benkaddour M and Benhadda T, J Appl Electrochem., 2005, 35(11), 1095-1101.

26. Abdel Rehim S S, Hazzazi O A, Amin M A and Khaled K F, Corros Sci., 2008, 50, 2258-2271.

27. Rudresh H B and Mayanna S M, Corros Sci., 1979, 19(6), 361-370.

28. Ferreira ES, Giancomelli C, Giacomelli F C and Spinelli A, Mater Chem Phys., 2004, 83, 129.

29. Li W, He Q, Zhang S, Pei C and Hou B, J Appl Electrochem., 2008, 38, 289-295.

30. Helal N H, El-Rabiee M M, Abd El-Hafez G M and Badawy W A, J Alloys Comp., 2008, 456(1-2), 372-378.

31. Huang W and Zhao J, Coll Surf A: Physicochem Eng Aspects, 2006, 278, 246.

32. Bouklah M and Hammouti B, Port Electrochim Acta, 2006, 24(4), 457-468.

33. Abdallah M, Corros Sci., 2004, 46(8), 1981-1996.

34. Martinez S and Stern I, Appl Surf Sci., 2002, 199, 83-89.

35. Abd El-Rehim S S, Ibrahim M A M and Khaled K F, J Appl Electrochem., 1999, 29, 593-599.

36. Lebrini M, Lagrenée M, Traisnel M, Gengembre L, Vezin H and Bentiss F, Appl Surf Sci., 2007, 253, 9267.

37. El-Etre A Y, Abdallah M and El-Tantawy Z E, Corro Sci., 2005, 47, 385-395.

38. Herrag L, Hammouti B, Aouniti A, El Kadiri S and Touzani R, Acta Chim Slov., 2007, 54(2), 419-423. 